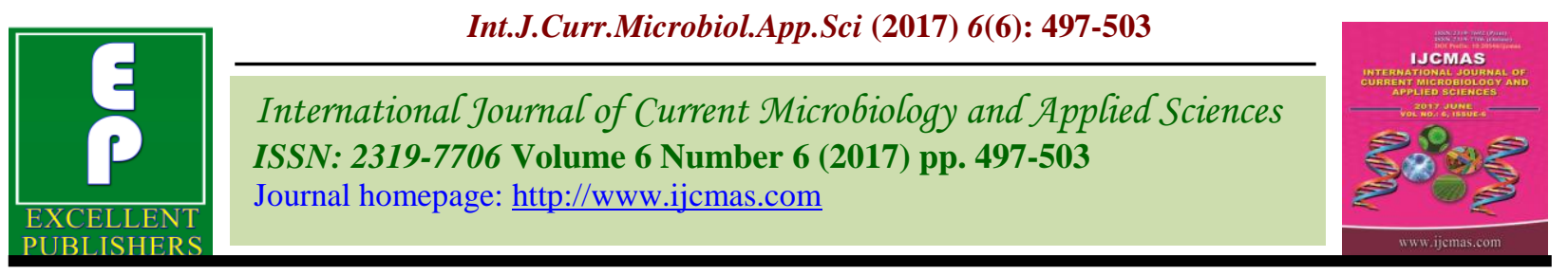

Original Research Article

https://doi.org/10.20546/ijcmas.2017.606.058

\title{
Effect of Different Varieties and FYM Levels on Yield and Quality of Onion (Allium cepa L.) in Arid Western Rajasthan, India
}

\author{
P.K. Kaswan*, P.K. Yadav, R.K. Jakhar, Amit Kumawat and Harish Kumar \\ Department of Horticulture, College of Agriculture, Swami Keshwanand Rajasthan Agricultural \\ University, Bikaner-334 006, India \\ *Corresponding author
}

\begin{tabular}{|c|c|}
\hline & A B S T R A C T \\
\hline & \multirow{7}{*}{$\begin{array}{l}\text { An experiment was conducted during Rabi season of } 2009-2010 \text { at } \\
\text { Horticulture Farm, Swami Keshwanand Rajasthan Agricultural University, } \\
\text { and Bikaner. The experiment comprising four varieties of onion viz., PDR, } \\
\text { RO-59, RO-252 and RO-282 and FYM levels viz., 0, 20, } 40 \text { and } 60 \mathrm{t} \mathrm{ha}^{-1} \text {. } \\
\text { A total of } 16 \text { treatment combinations were evaluated in randomized block } \\
\text { design with three replications. The results indicated that plant height, } \\
\text { number of leaves per plant, moisture content of bulb, neck thickness, } \\
\text { diameter of bulb, volume of bulb, bulb yield, TSS and N, P and K uptake } \\
\text { were maximum under the variety RO-252. Application of FYM @ } 40 \text { t/ha } \\
\text { significantly increased number of leaves per plant, moisture content of } \\
\text { bulb, neck thickness, diameter of bulb, volume of bulb, bulb yield, TSS, } \\
\text { Pungency and N, P and K content and uptake however, plant height at } 60 \\
\text { DAT was maximum with the application of } 60 \mathrm{tFYM/ha.}\end{array}$} \\
\hline & \\
\hline $\begin{array}{l}\text { Bulb, } \\
\text { Farm yard manure, }\end{array}$ & \\
\hline $\begin{array}{l}\text { Moisture, } \\
\text { Onion, } \\
\text { Varieties and } \\
\text { Volume. } \\
\end{array}$ & \\
\hline Article Info & \\
\hline $\begin{array}{l}\text { Accepted: } \\
\text { 04 May } 2017 \\
\text { Available Online: } \\
\text { 10 June } 2017\end{array}$ & \\
\hline & \\
\hline
\end{tabular}

\section{Introduction}

Onion (Allium cepa L.) is one of the commonest and indispensable vegetable cum condiment crop grown for local consumption, export and processing and is used as salad and cooked in various ways in all curies, fried, boiled, baked, soup making and in pickles. Soils of Western Rajasthan, particularly in Bikaner district, contain very low clay (4-6\%) and organic matter (0.08), N (0.50), P (0.25) and $\mathrm{K}$ (0.50). Farmyard manure rich in organic matter can be supplemented with $\mathrm{N}, \mathrm{P}$ and $\mathrm{K}$ fertilizers. FYM not only provides most of the essential plant nutrients but also improves soil structure through binding effect on soil aggregates, cation exchange capacity, water holding capacity, fertilizers use efficiency, microbial activity and nutrient availability in soil. Farm yard manure with chemical fertilizers and their method of application help in improving the fertility and productivity and physical condition of soil (Abusaleha and Shamugvelu, 1998). Among the various factors responsible for higher yield potential, the application of adequate quantities of Farm Yard Manure is considered as one of the most effective way to boosting the crop yield (Mohanty and Prusti, 2001 and Singh et al., 1995) in soils of western 
Rajasthan. The main reason for low productivity is lack of suitable varieties for cultivation in arid areas. Most of the farmers are illiterate and always remain under confusion about recommended varieties. One of the important aspects of improvement in yield and quality of onion is the selection of suitable cultivars to a particular agro-climatic region.

\section{Materials and Methods}

The experiment was conducted on loamy sand soil at Horticulture Farm, College of Agriculture, Swami Keshwanand Rajasthan Agricultural University, Bikaner, during Rabi season 2009-2010. The experiment comprising four varieties of onion viz., PDR, RO-59, RO-252 and RO-282 and FYM levels viz., $0,20,40$ and $60 \mathrm{t} / \mathrm{ha}$. A total of 16 treatment combinations were evaluated in randomized block design with three replications. The seven week old seedlings of four varieties of onion viz., PDR, RO-59, RO252 and RO-282 were transplanted with spacing of $15 \times 10 \mathrm{~cm}$ in second December 2009. The irrigation was applied through drip system consisted of $16 \mathrm{~mm}$ laterals having drippers at $40 \mathrm{~cm}$ distance. Each plot consisted of 3 laterals at $80 \mathrm{~cm}$ apart and four rows of onion were planted at each lateral. As per treatment FYM was applied at the time of field preparation and chemical fertilizers i.e. nitrogen, phosphorus and potassium (100, 50 and $100 \mathrm{~kg} / \mathrm{ha}$ ) were applied through Urea, DAP and MOP.

\section{Results and Discussion}

\section{Effect of varieties}

Among different varieties, RO-252 produced significantly higher plant height and maximum number of leaves per plant at 60 days after transplanting over rest of the varieties (Table 1). Plant height and number of leaves per plant are the genetic characters and hence different varieties varied with respect to these characters which ultimately brought about variation in these characters. This finding corroborate with the results of Mohanty and Prusti (2001). RO-252 variety produced significantly higher moisture content of bulb. This might be due to characteristics of this variety that increased vegetative growth in terms of plant height and number of leaves per plant which resulted in higher moisture content of bulb. These characters play a vital role in various metabolic processes primarily that results in increased net photosynthesis and helps in the translocation of photosynthates in storage organ of bulb resulting in increased weight of bulb. Diameter and volume of bulb and bulb yield were found significantly higher in RO252 however, significantly lesser neck thickness was found in same variety. This might be due to characteristics of these varieties that increased vegetative growth with extended frame work of plant. The bulb yields being primary function of cumulative effect of these parameters. Improved fresh weight of leaves and bulb with varietal characters leading to significant improvement in bulb yield and resulted in better source and sink relationship. Similar results were observed by Khar et al., (2007) in onion. Allyl- propyl disulphide was recorded highest in PDR variety than the other varieties of onion (Table 2). This might be due to characteristics of this variety that slightly increased trend leads to increase of volatile and fatty oil content resulting in significantly higher production of allyl-propyl disulphide in onion bulbs. Increased in allyl-propyl disulphide with variety PDR was in close agreement with those of Abbey et al., (2005) in onion. Highest TSS content $\left(12.03{ }^{\circ}\right.$ Brix $)$ was recorded in $\mathrm{RO}-252$ variety of onion followed by RO-59, RO-282 and PDR which was 2.82, 2.99 and 6.64 per cent higher over RO-59, RO-282 and PDR, respectively. However, there was non-significant difference 
observed between RO-59 and RO-282.The varietal character increased total soluble solids, nitrogen, phosphorus and potassium content and uptake which were found maximum in RO-252. This might be due to vigorous vegetative growth and imparts deep green colour of the foliage which favoured photosynthetic activity of the plants. Due to this there was greater accumulation of food material i.e. carbohydrate in the bulb. There was more synthesis of T.S.S. Similar observations were also reported by Khar et al., (2007) and Zhong et al., (1997) in onion.

\section{Effect of FYM}

The maximum plant height at 60 DAT was observed with the application of 60 tonnes FYM (Table 1). However, the maximum number of leaves per plant was recorded with FYM 40 t/ha. This might be due to the fact that application of FYM resulted in vigorous vegetative growth of the plant and imparted dark green colour to the foliage which favoured photosynthetic activity of the plant and greater synthesis of carbohydrate in the leaves leading to formation of amino acids, nucleo-proteins, chlorophyll, alkaloids and amides. These complex compounds are responsible for building up of new tissues and are associated with a number of metabolic processes, which in turn favoured better development of plant. These results are in agreement with the findings of Rafi et al., (2002) in tomato, Ghuge et al., (2007) also observed better growth in cabbage with organic manure application. Maliangouda et al., (1995) reported application of FYM and NPK improved plant height and number of branches in chilli. Manolikar et al., (2007) reported that the application of farm yard manure $40 \mathrm{t} / \mathrm{ha}$ along with $50 \% \mathrm{RDF}$ produced maximum height of plant in tomato.

In general, the significant improvement in yield attributes of onion with the farm yard manure could be ascribed to overall improvement in vigour and crop growth as already explained in preceding paragraphs. Since an adequate and small amount of major nutrients supplied through FYM in the life of a plant is considered important in promoting rapid fresh weight and dry weight of bulb in terms of bulb size, diameter of bulb, volume of bulb and bulb yield. These parameters were recorded significantly higher with application of 40 tonnes FYM per hectare. FYM coupled with increased net photosynthesis and helps in the translocation of photosynthates in storage organ of bulb resulted in increased diameter and weight of bulbs (Singh et al., 1995 and Mallangouda et al., 1995). The bulb yield being a primarily function of cumulative effect of these parameters, significantly increased by $315.17 \mathrm{q} / \mathrm{ha}$ with FYM at 40 t/ha.

The beneficial effects of farm yard manure on yield attributes were probably due to enhanced supply of macro as well as micronutrients during entire growing season. It might have attributed to higher manufacture of food and its subsequent partitioning in sink. The availability and supply of nutrients to plants favourably influenced the flowering and fruit formation, ultimately increased the bulb yield. The FYM might enhance the efficiency of uptake of native and soil nutrients. The reason for increased bulb yield with the application of farm yard manure could be attributed to solubilization effect of plant nutrients by the addition of FYM leading to increased uptake of nutrients especially NPK as reported by Raina and Jaggi (2008) in onion and Singh and Janardan (2004) in potato. The improvement in bulb weight and yield of onion in response to farm yard manure application is possibly attributed to improved soil physical conditions and slow release availability of nutrients (Dimri and Singh, 2005). 
Table.1 Effect of varieties and FYM levels on growth and yield of onion

\begin{tabular}{|c|c|c|c|c|c|c|c|}
\hline Treatments & $\begin{array}{c}\text { Plant height } \\
(\mathrm{cm}) \text { at } 60 \\
\text { DAS }\end{array}$ & $\begin{array}{c}\text { No. of leaves } \\
\text { per plant at } 60 \\
\text { DAS }\end{array}$ & $\begin{array}{c}\text { Moisture } \\
\text { content of bulb } \\
(\%)\end{array}$ & $\begin{array}{l}\text { Neck thickness } \\
\qquad(\mathrm{cm})\end{array}$ & $\begin{array}{l}\text { Diameter of } \\
\text { bulb }(\mathrm{cm})\end{array}$ & $\begin{array}{l}\text { Volume of } \\
\text { bulb (cc) }\end{array}$ & $\begin{array}{l}\text { Bulb yield } \\
\left.(\mathrm{q} \mathrm{ha})^{-1}\right)\end{array}$ \\
\hline \multicolumn{8}{|l|}{ Varieties } \\
\hline $\operatorname{PDR}\left(\mathrm{V}_{1}\right)$ & 54.45 & 6.5 & 11.27 & 1.53 & 4.69 & 53.73 & 251.88 \\
\hline $\mathrm{RO}-59\left(\mathrm{~V}_{2}\right)$ & 54.43 & 6.85 & 15.99 & 2.01 & 5.06 & 55.58 & 268.14 \\
\hline $\mathrm{RO}-252\left(\mathrm{~V}_{3}\right)$ & 56.17 & 7.15 & 18.21 & 2.28 & 5.34 & 57.98 & 290.49 \\
\hline $\mathrm{RO}-282\left(\mathrm{~V}_{4}\right)$ & 53.98 & 7.05 & 16.39 & 2.13 & 5.22 & 54.90 & 258.39 \\
\hline S. Em \pm & 0.51 & 0.07 & 0.43 & 0.04 & 0.10 & 0.80 & 5.63 \\
\hline C.D. at $5 \%$ & 1.48 & 0.21 & 1.25 & 0.11 & 0.28 & 2.31 & 16.27 \\
\hline \multicolumn{8}{|c|}{ Levels of FYM (t/ha) } \\
\hline Control $\left(\mathrm{F}_{0}\right)$ & 51.87 & 6.53 & 13.2 & 1.64 & 3.68 & 40.78 & 182.18 \\
\hline $20\left(\mathrm{~F}_{1}\right)$ & 53.7 & 6.7 & 15.13 & 1.94 & 4.63 & 55.13 & 242.01 \\
\hline $40\left(\mathrm{~F}_{2}\right)$ & 55.53 & 7.07 & 16.26 & 2.14 & 5.87 & 62.47 & 315.17 \\
\hline $60\left(\mathrm{~F}_{3}\right)$ & 57.93 & 7.25 & 17.27 & 2.23 & 6.13 & 63.82 & 329.53 \\
\hline S. Em \pm & 0.51 & 0.07 & 0.43 & 0.04 & 0.10 & 0.80 & 5.63 \\
\hline C.D. at $5 \%$ & 1.48 & 0.21 & 1.25 & 0.11 & 0.28 & 2.31 & 16.27 \\
\hline
\end{tabular}


Table.2 Effect of varieties and FYM levels on quality parameters of onion

\begin{tabular}{|c|c|c|c|c|c|c|c|c|}
\hline \multirow[t]{2}{*}{ Treatments } & \multirow[t]{2}{*}{ TSS ( ${ }^{\circ}$ Brix $)$} & \multirow{2}{*}{$\begin{array}{l}\text { Allyl-propyl disulphide } \\
\text { content }(\mathrm{mg} / 100 \mathrm{~g})\end{array}$} & \multicolumn{3}{|c|}{ Nutrient content (\%) } & \multicolumn{3}{|c|}{ Nutrient uptake (kg/ha) } \\
\hline & & & Nitrogen & Phosphorus & Potassium & Nitrogen & Phosphorus & Potassium \\
\hline \multicolumn{9}{|l|}{ Varieties } \\
\hline $\operatorname{PDR}\left(\mathrm{V}_{1}\right)$ & 11.28 & 5.59 & 0.860 & 0.581 & 0.985 & 23.92 & 16.30 & 27.36 \\
\hline $\mathrm{RO}-59\left(\mathrm{~V}_{2}\right)$ & 11.70 & 5.34 & 0.879 & 0.628 & 0.979 & 25.94 & 18.64 & 28.80 \\
\hline $\mathrm{RO}-252\left(\mathrm{~V}_{3}\right)$ & 12.03 & 5.32 & 0.880 & 0.646 & 0.992 & 27.92 & 20.51 & 31.45 \\
\hline $\mathrm{RO}-282\left(\mathrm{~V}_{4}\right)$ & 11.68 & 5.44 & 0.865 & 0.654 & 0.995 & 24.72 & 18.71 & 28.28 \\
\hline $\mathrm{S} . \mathrm{Em} \pm$ & 0.11 & 0.05 & 0.005 & 0.007 & 0.002 & 0.55 & 0.43 & 0.55 \\
\hline C.D. at $5 \%$ & 0.31 & 0.15 & 0.013 & 0.021 & 0.006 & 1.60 & 1.25 & 1.59 \\
\hline \multicolumn{9}{|c|}{ Levels of FYM (t/ha) } \\
\hline Control $\left(\mathrm{F}_{0}\right)$ & 10.98 & 5.18 & 0.843 & 0.586 & 0.974 & 17.44 & 12.14 & 20.12 \\
\hline $20\left(\mathrm{~F}_{1}\right)$ & 11.53 & 5.37 & 0.862 & 0.621 & 0.984 & 23.04 & 16.60 & 26.27 \\
\hline $40\left(\mathrm{~F}_{2}\right)$ & 11.94 & 5.51 & 0.887 & 0.648 & 0.996 & 30.29 & 22.11 & 33.96 \\
\hline $60\left(\mathrm{~F}_{3}\right)$ & 12.23 & 5.62 & 0.891 & 0.654 & 0.998 & 31.73 & 23.31 & 35.54 \\
\hline S. Em \pm & 0.11 & 0.05 & 0.005 & 0.007 & 0.002 & 0.55 & 0.43 & 0.55 \\
\hline C.D. at $5 \%$ & 0.31 & 0.15 & 0.013 & 0.021 & 0.006 & 1.60 & 1.25 & 1.59 \\
\hline
\end{tabular}


The application of farm yard manure up to 40 t/ha significantly increased the total soluble solids (TSS) content in comparison to control and other doses of FYM (Table 2). The maximum TSS in bulb was recorded with FYM @ 40 t/ha. The improvement in TSS might be due to the known fact that organic manures (farm yard manures) are capable of supplying adequate macro and micro plant nutrients which play a major role in quality improvement through desirable enzymatic changes taking place during growth. Higher nutrient contents in leaves and bulb also seems to be attributed to higher functional activity of roots for lower duration under this treatment. Similar results were obtained by Gupta et al., (1999) and Bairwa et al., (2009). The pungency of onion increased with the increasing doses of FYM up to 60 t/ha than the control. The increase in pungency of onion at higher level of FYM was due to increase in synthesis and translocation of sulphur to the onion (Raina and Jaggi, 2008).

Application of $40 \mathrm{t}$ FYM/ha significantly increased the nitrogen, phosphorus and potassium contents and uptake in plants over its lower doses but remained at par with $60 \mathrm{t}$ FYM/ha. The positive influence of FYM on $\mathrm{N}, \mathrm{P}$ and $\mathrm{K}$ contents in plants was due to improved nutritional environment in the dense root zone of the plants. Thus adequate supply of FYM early in the crop season resulted in greater availability of nutrients including $\mathrm{N}, \mathrm{P}$ and $\mathrm{K}$ in particular root zone. Nutrient availability increased in the root zone coupled with increased metabolic activity at the cellular level might have increased the nutrients uptake and accumulation in vegetative plant parts. The NPK uptake increased under organic treatments as compared to control. The probable reason for this increase was that, sources of organic manures applied to onion might have improved nutrient availability in soil and thus benefited the crop. Secondly, higher bulb yield obtained with organic sources also resulted in better uptake of nutrients from soil. Higher uptake at maximum fertility level might be due to more nutrient content and yields which removed more nutrients from soil (Sarkar and Mondal, 2005).

\section{References}

Abbey, L., Joyce, D. C., Aked, J. and Smith, B. 2005. Evaluation of eight spring onion genotypes, sulphur nutrition and soil-type effects with an electronic nose. J. Hort. Sci. Biotechnol., 80(3): 375 381.

Abusaleha and Shanmugavelu, K.G. 1998. Studies on the effect of organic v/s. inorganic sources of nitrogen on growth, yield and quality of okra [Abelmoschus esculentus (L.) Moench]. Indian Journal of Horticulture, 45(2): $312-318$

Bairwa, H. L., Shukla, A. K. Mahawer, L. N., Kaushik, R. A., Shukla, K. B. and Ameta, K. D. 2009. Response of integrated nutrient management on yield, quality and physio-chemical characteristics of okra cv. Arka Anamika. Indian Journal of Horticulture, 66(3): $310-314$.

Dimri, D.C. and Singh V.P. 2005. Response of farm yard manure, nitrogen and row spacing on bulb weight and yield of onion (Allium cepa L.) cv. VL-3. Progressive Horticulture, 37(1): 185 187.

Ghuge, T.D., Gore, A.K. and Jadhav, S.B. 2007. Effect of organic and inorganic nutrient sources on growth, yield and quality of cabbage (Brassica oleracea var. capitata). Journal of Soil and Crops, 17: $89-92$.

Gupta, R. P., Sharma, V. P., Singh, D. K. and Srivastava, K. J. 1999. Effect of organic manure and inorganic fertilizer on growth, yield and quality of onion cv. 
Agri Found Dark Red. Newsletter National Horticultural Research and Development Foundation, 19 (2/3): 7 11.

Khar, A., Devi, A., Asha, Mahajan, V. and Lawande, K. E. 2007. Stability analysis of some elite onion lines in late kharif season. Indian Journal of Horticulture, 64: 32-36.

Mallangouda, B., Sulikeri, G.S., Murthy, B.G. and Patibha, N.C. 1995. Effect of NPK, FYM and companion crops on growth, yield and yield component of chilli (Capsicum annum L.). Adv. Agril. Res. India, 3: $58-59$.

Manolikar, R. R., Vitkar, M. N., Vasmate, S. D., Patil, R. F. and Kalalbandi, B.M. 2007. Effect of integrated nutrient management on growth and yield of tomato (Lycopersicon esculentum Mill.). The Asian Journal of Horticulture, 2: 178 - 180.

Mohanty, B.K. and Prusti, A.M. 2001. Performance of common onion varieties in kharif seasons. Indian Journal of Tropical Agriculture, 39: 21 - 23.

Rafi, Mohmad, Narwadkar, P.R., Prabu, T. and Sajindranath, A.K. 2002. Effect of organic and inorganic fertilizers on growth and yield of tomato
(Lycopersicon esculentum Mill). South Indian Hort., 50(4-6): 522 - 526.

Raina, S.K. and Jaggi, R.C. 2008. Effect of sulphur in presence and absence of farm yard manure on onion (Allium cepa L.) under onion-maize (Zea mays) cropping sequence. Indian Journal of Agriculture Sciences, 78(8): $659-662$.

Sarkar, B. and Mondal, S.S. 2005. Effect of integrated nutrient management on the growth and productivity of potato (Solanum tuberosum). Environment and Ecology, 23(3): 387 - 391.

Singh, S. K. and Janardan, J. 2004. Effect of organic and inorganic sources of nutrition on productivity, economics and nutrient uptake of potato. First Indian Horticulture Congress held at New Delhi. Abstracts. pp. 260.

Singh, V., Singh R. K. and Singh, V. 1995. Response of onion (Allium cepa L.) to $\mathrm{N}, \mathrm{P}, \mathrm{Zn}$ and FYM. Annals of Agricultural Research, 16: 79 - 81 .

Zhong Song, Zhang Dipei, Weiyouying, Li-Ji Rong, Sun Hejun and Zhang, S. 1997. Analysis of soluble solids, dry matter, soluble sugar and ethereal oil in welsh onion (Allium fistulasum L.). Journal of Shandong Agricultural University, 28: $2477-2482$.

\section{How to cite this article:}

Kaswan, P.K., P.K. Yadav, Harish Kumar, R.K. Jakhar, Amit Kumawat and Harish Kumar. 2017. Effect of different varieties and FYM levels on yield and quality of onion (Allium cepa L.) in Arid Western Rajasthan, India. Int.J.Curr.Microbiol.App.Sci. 6(6): 497-503. doi: https://doi.org/10.20546/ijcmas.2017.606.058 